\begin{tabular}{|l|l|l|l|}
\hline ACTA CLASSICA & LIII. & 2017. & \\
UNIV. SCIENT. DEBRECEN. & & & pp. 37-42. \\
\hline
\end{tabular}

\title{
THE AMBIGUOUS ARMS OF AENEAS
}

\author{
BY LEE FRATANTUONO
}

\begin{abstract}
Virgil subtly connects the scene of Dido's discussion with her sister Anna about the new Trojan arrival Aeneas, and the later first arrival of the Trojans in Latium. By a careful correspondence between the two passages, Virgil portends the dark amatory rationale behind the subsequent outbreak of war in Italy.

Keywords: Aeneas, Carthage, Dido, Latium, Troy
\end{abstract}

Dido's address to her sister Anna in the first movements of Book IV of Virgil's Aeneid contains a well-known ambiguity in the matter of the "arms" of Aeneas:

quis novus hic nostris successit sedibus hospes,

quem sese ore ferens, quam forti pectore et armis! $!^{1}$

Does Dido refer to Aeneas' weaponry and martial prowess, or to his presumably broad, muscular shoulders? Is the lexical ambiguity a deliberate trick of the poet, with reference both to Dido's appreciation and admiration of Aeneas' military panoply, and of his striking physical appearance? ${ }^{2}$ Or are overly clever critics wrong to think of armus in a context that perhaps so clearly calls for arma and arma alone? ${ }^{3}$

\footnotetext{
${ }^{1}$ All quotes from Virgil's Aeneid are taken from Conte 2009. I am grateful for the helpful editorial assistance of Prof. Tamás Gesztelyi, and to Prof. Blaise Nagy.

${ }^{2}$ Arma, we might note, is not without its own associations with physical appearance and sexuality; on this see further Newman - Newman 2005, 59 (and cf. 143). Dido was struck from the start by Aeneas' aspectus (cf. I 613).

${ }^{3}$ The classic discussion is that of Henry 1878 (with vigorous argument in favor of taking armis from armus, not arma); Henry is followed by Austin 1955 ad loc. More cautious on this point is Pease 1935. Among school commentators, O'Hara 2011 admits the possibility of deliberate ambiguity ad loc.; so also Maclennan 2007. Page considers the derivation from armus to be an example of "perverse ingenuity" (as if Dido were appraising a horse); Mackail and Williams share his skepticism. Sigdwick acknowledges the possible meaning of "shoulders,", though with doubts; Papillon and Haigh settle on arma. Among other commentators, Wagner, Ladewig, Forbiger
}

doi $10.22315 / A C D / 2017 / 3$ 
Interpretation of this passage has usually included consideration of the somewhat parallel case of XI 640-642 (during the equestrian battle before the walls of Latinus' capital), where Tiburtine Catillus strikes down first Iollas and then Herminius. Virgil provides a brief description of the doomed warriors, giants both:

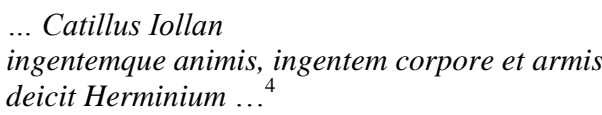

Here the armis may refer to the shoulders of the huge Herminius (cf. XI 644 ... latos huic ... per armos), or to his weapons; the poet at once makes clear that the hero's humeri are in fact bereft of defensive arms: ... nudo cui vertice fulva I caesaries nudique armi nec vulnera terrent (XI 642-643). ${ }^{5}$ The brief vignette of the blond Herminius plays on the diverse senses of "arms"; Herminius is ingentem armis - huge with respect either to his shoulders or his weapons - and his confidence in his own strength and fortitude permits him to expose himself fearlessly to the clash and din of arms around him (XI 644 tantus in arma patet). All the same, he is soon enough felled by a spear that is driven through his shoulders (XI 644 ... per armos). Three "arms" in succession then: the second certainly of weapons, the third of shoulders (neuter plural accusative and masculine plural accusative); the first is ambiguous (ablative plural).

There are other Virgilian passages where a form of armus (and not arma) certainly occurs. At VI 881 and XI 497, armos is used of the flanks of a horse; at X 711 of the forequarters of a wild boar; and at XII 722 of the shoulders of bulls; the noun is normal Latin for describing the "arms" of animals, though the distinction between armus of an animal and humerus of a human is not strictly maintained. ${ }^{6}$ At X 894 ... eiecto ... armo describes the dislocated limb of Mezentius' horse Rhaebes. ${ }^{7}$ Scholars who derive IV 11 armis from arma and not armus often employ the "animal argument" and conclude that the poet

("i.e. bracchiis") and Conington prefer armus; Gossrau and Benoist arma; Paratore is silent. Peerklamp notes: "Os, pectus, et arma, sic iunguntur, ut cuncta proprie accipere debeamus." One could argue that ore, pectore, and armis may all refer to the Trojan hero's physical appearance; cf. Dido's comment on Aeneas' visage at IV 329. See further, too, Schauer 2007, 184-185. On the pectus of Aeneas to which Dido refers, note Negri 1984, 204, 257, 259, 288.

${ }^{4}$ On this passage see further ad loc. Horsfall 2003 (who takes armis from arma); also Gransden 1991 (with preference for armus), and Fratantuono 2009 (favoring studied ambiguity).

${ }^{5}$ Henry here (Aeneidea ... Vol. IV, Dublin, 1889) deplores the Virgilian ambiguity.

${ }^{6}$ Cf. also G. III 86; Plautus, Agroecus fr. 5 Lindsay - De Melo quasi lupus ab armis valeo, clunes infractos fero.

${ }^{7}$ See here Harrison 1991, ad loc.; Pease ad IV 11 strangely takes it of a human shoulder/arm (i.e., of Mezentius). 
would not use armi of the shoulders of either Aeneas or, for that matter, Herminius.

But there is another passage in the Aeneid that has not been considered closely in relation to the ambiguity of IV 11 - another passage that raises the question of just what "arms" are being referenced. The scene is Latinus' palace in central Italy, in the wake of the arrival of the Trojan exiles in Latium. The Trojan herald Ilioneus makes a solemn assurance to the Latin king:

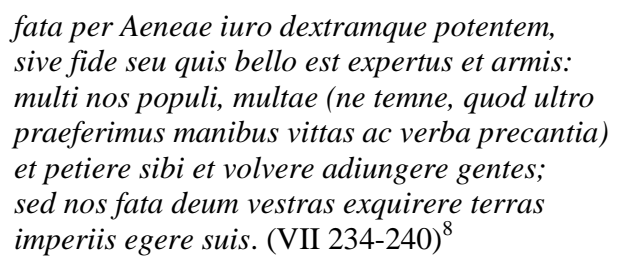

Ilioneus swears by the fate or destiny of Aeneas and the hero's powerful right hand to which many nations have sought to join themselves to forge an alliance with the Trojans. ${ }^{9}$ The fates ordained by the gods, however (VII 239 sed is adversative) have ordained that the Trojans should seek Latinus' kingdom (i.e., and not remain with previous hosts and willing comrades); there is something of a studied, deliberate contrast in this passage between the fata Aeneae and the fata deum that frame it. ${ }^{10}$

Ilioneus' point about the multi populi and multae gentes is somewhat exaggerated. His reference looks back both to Book V and the sojourn with Acestes' Sicilians, and (especially) to Book IV and the more fateful months spent in Dido's Carthage, the latter of which also commenced with an exchange between Ilioneus and a foreign potentate. ${ }^{11}$ Rhetorical embellishment on this point may be forgiven more or less readily in context; Ilioneus is eager to present Aeneas and the Trojans in the most positive light possible. Of particular interest here is the reflection Ilioneus makes on Aeneas' "powerful right hand" (VII 234 ... dextramque potentem), the hand whereby he proffers a histrionic declaration. Aeneas' spokesman notes that Aeneas' hand has been found potens or power-

\footnotetext{
${ }^{8}$ On this passage note especially Horsfall 2000, ad loc.; also Monti 1981, 11 ff.; Smith 2005, 134-135.

${ }^{9}$ On how Ilioneus uses the language of "wooing" (which would only further underscore the reminiscence of Aeneas' time with Dido), see Reed 2007, 90-91.

${ }^{10}$ For fata deum of oracular utterances, see Fordyce 1977, ad loc. We may recall how Aeneas indicated to Dido that he was leaving Carthage against his will (IV 361 Italiam non sponte sequar).

${ }^{11}$ Cf. Dido's words to Ilioneus at I 573-574 urbem quam statuo, vestra est: subducite navis; / Tros Tyriusque mihi nullo discrimine agetur.
} 
ful, whether one has tested it for loyalty, or for war and arms (VII 235 sive fide seu quis bello est expertus et armis).

Fides is a crucial concept and term in the Aeneid, and it has particular application and relevance to the experience of Dido and Aeneas. ${ }^{12}$ Dido considers Aeneas to be perfidus in the wake of the realization that he intends to leave North Africa (IV 305; 366 perfide, perfide; 421 perfidus ille), and she notes ruefully that fides is never safe and secure (IV 373 nusquam tuta fides). ${ }^{13}$ Not long before her suicide, she makes the observation to herself that she has not kept faith with her dead husband Sychaeus (IV 552 non servata fides cineri promissa Sychaeo). And in the end, as she sees Aeneas' fleet sail away from her shores, she makes a critical comment on the Trojan hero's lack of a sense of loyalty and faith, a sarcastic utterance that also makes reference to Aeneas' right hand (IV 597 ... en dextra fidesque). ${ }^{14}$

Dido's indictment of Aeneas' dextra and fides also recalls how Aeneas had reported his conveyance of the Trojan household gods and his aged father Anchises out of the burning wreck of Priam's city:

quem secum patrios aiunt portare penates,

quem subiisse umeris confectum aetate parentem! (IV 598-599) ${ }^{15}$

Dido critiques and implicitly questions the faith and surety of the man who had seemingly boasted of his pietas and sense of duty and loyalty. ${ }^{16}$

Ilioneus' declaration to Latinus' court consists of a threefold comment on the power of Aeneas' right hand; the truth of the herald's judgment is known, he remarks, whether one has experienced the Trojan hero's right hand in fides, bellum, or in "arms" (ablative plural armis). Fides and bellum are deliberately juxtaposed; armis from arma would be a reinforcement and expansion of the reference to bellum. With reference to Aeneas, the mention of war recalls most especially the struggle against the invading Greeks at Troy. ${ }^{17}$

\footnotetext{
${ }^{12}$ See further here R. Samuels, "Fides and Foedus," In: Thomas - Ziolkowski 2013, 481482; also C. Venturini: "Fides.”. In: Della Corte 1985, 509-511.

${ }^{13}$ On how Virgil manipulates the stereotypical faithlessness of the Carthaginians in his depiction of Aeneas' relationship with Dido, see especially Starks 1999.

${ }^{14}$ The hand that in her assessment had been given to her in marriage.

${ }^{15} \mathrm{Cf}$. also II, 721, where Aeneas describes his latos umeros on which he bore the burden of his father; on this image and the physical description (with reference to IV 11), note Heuzé 1985, 20 .

${ }^{16}$ Paratore notes here, “. ... ripete proprio la frase di Enea in II 708 subibo umeris, quasi che Didone volesse riecheggiare ironicamente il racconto fattole da Enea.” (Paratore 1978, ad loc.)

${ }^{17}$ For the collocation of war and arms, cf. I 544-545 rex erat Aeneas nobis, quo iustior alter I nec pietate fuit, nec bello maior et armis (where Ilioneus describes Aeneas to Dido's court; on the construction and implications of the comment, see further Austin 1971, ad loc.); also the
} 
But here - as at the start of Book IV - the reference to "arms" carries it with a deliberate ambiguity. The armis at the end of verse 235 balance the dextramque potentem at the close of 234 , and convey an allusion to the powerful, handsome shoulders of the Trojan hero that so captivated Dido in the wake of her banquet hosting for Aeneas in Carthage. ${ }^{18}$ The "right hand" and "arms" of Aeneas recall, too, the right hand that Dido freely gave to Aeneas in what she thought was conjugal union as well as military and political alliance. ${ }^{19}$

When Ilioneus described his commander Aeneas to Dido at the Trojan reception in Juno's temple, the herald noted first Aeneas' pietas, and then his prowess in war and in arms (I 544-545). ${ }^{20}$ Dido's description of Aeneas to her sister Anna at IV 11 also offered a threefold commentary, namely on the Trojan hero's os, pectus, and armalarmi. In the context of Ilioneus' address in the first book of the epic, the "arms" of Aeneas point only to the great warrior's mastery of weaponry and the arts of combat. By the time the Trojan spokesman addresses Latinus' court in the first book of the poem's second half, the "arms" of Aeneas have taken on another shade of meaning and allusive comment in light of the hero's Carthaginian sojourn. Dido's admiration of Aeneas' physical charms, the long winter spent in questionable emotional and sexual union, and the ultimate tragedy of Aeneas' enforced departure from his Carthaginian lover all serve to blur the implications of armis.

Ilioneus' first mission on behalf of Aeneas was to Dido; ultimately the relationship between Trojans and Carthaginians would be doomed. In Latium, the new mission is to Latinus' kingdom, and here, too, dark shadows gather - war will erupt before the end of the same book. Because of the reader's knowledge of Dido's private exchange with her sister, and the very public drama of the subsequent events in Carthage, Ilioneus' introduction of Aeneas to Latinus carries with it an inadvertent backward glance to not only the record of Aeneas in war, but also to the fides that was confirmed by the arms with which the lovers made their doomed embrace. The ominous reminiscence of Carthage's queen

language of Dido's curse at IV 615 at bello audacis populi vexatus et armis. On the phrase note Horsfall on VII 235, who takes it as "A stock phrase ... 'paired synonyms' or pleonasm ... in both prose and verse, but not, it appears, very old."

${ }^{18}$ May we recall, too, how when Dido is compared to Diana in her initial appearance at I 494 ff., the first physical description the poet offers is how the goddess had a quiver on her shoulder and towered over her attendant nymphs? Weapons also sound on the shoulders of the Apollo to whom Aeneas is compared at IV 149, at the opening of the fateful hunt in Carthage. On the parallelism of the two lovers see especially Mackie 1988, 78.

${ }^{19}$ IV 307-308 nec te noster amor nec te data dextera quondam / nec moritura tenet crudeli funere Dido?

${ }^{20}$ For how Aeneas may well be depicted not so much for pietas as for violating hospitium in the Carthage sequences, see Gibson 1999. 
serves in part as foreshadowing of how Ilioneus' second embassy will, like the first, end in tragedy.

\section{Bibliography}

Austin 1955 = Austin, R. G.: P. Vergili Maronis Aeneidos Liber Quartus. Oxford.

— $1971=$ Austin, R. G.: P. Vergili Maronis Aeneidos Liber Primus. Oxford.

Conte $2009=$ Conte, G. B.: P. Vergilius Maro: Aeneidos. Berlin-New York.

Della Corte 1985 = Della Corte, F.: Enciclopedia Virgiliana II. Roma.

Fordyce 1977 = Fordyce, C. J.: P. Vergili Maronis Aeneidos Libri VII-VIII. Oxford.

Fratantuono 2009 = Fratantuono, L. M.: A Commentary on Virgil, Aeneid XI. Bruxelles.

Gibson 1999 = Gibson, R. K.: Aeneas as hospes in Vergil, Aeneid 1 and 4. CQ 49, 184-202.

Gransden 1991 = Gransden, K. W.: Virgil, Aeneid XI. Cambridge.

Henry 1878 = Henry, J: Aeneidea, or Critical, Exegetical, and Aesthetical Remarks on the Aeneis, Vol. II. Dublin.

Harrison 1991 = Harrison, S. J.: Vergil: Aeneid 10. Oxford.

Heuzé 1985 = Heuzé, P.: L'image du corps dans l'œuvre de Virgile. Rome.

Horsfall $2000=$ Horsfall, N.: Virgil, Aeneid 7. Leiden.

- 2003 = Horsfall, N.: Virgil, Aeneid 11. Leiden.

Mackie 1988 = Mackie, C. J.: The Characterisation of Aeneas. Edinburgh.

Maclennan 2007 = Maclennan, K.: Virgil, Aeneid IV. London.

Monti 1981 = Monti, R. C.: The Dido Episode and the Aeneid: Roman Social and Political Values in the Epic. Leiden.

Negri 1984 = Negri, A. M.: Gli psiconimi in Virgilio. Roma.

Newman - Newman 2005 = Newman, J. K. - Newman, F. S.: Troy's Children: Lost Generations in Virgil's Aeneid. Hildesheim.

O'Hara 2011 = O'Hara, J.: Vergil: Aeneid 4. Newburyport.

Paratore 1978 = Paratore, E.: Virgilio Eneide, Volume II, Libri III-IV. Milano.

Pease $1935=$ Pease, A. S.: P. Vergili Maronis Liber Quartus. Cambridge, Mass.

Reed 2007 = Reed, J. D.: Virgil's Gaze: Nation and Poetry in the Aeneid. Princeton.

Schauer 2007 = Schauer, M.: Aeneas dux in Vergils Aeneis: Eine literarische Fiktion in augusteischer Zeit. München.

Smith 2005 = Smith, R. A.: The Primacy of Vision in Virgil's Aeneid . Austin.

Starks $1999=$ Starks, J. H. Jr.: Fides Aeneia : The Transference of Punic Stereotypes in the Aeneid. CJ 94, 255-283.

Thomas - Ziolkowski 2013 = Thomas, R. - Ziolkowski, J.: The Virgil Encylcopedia. Malden, MA.

(ISSN $0418-453 X)$ 